\title{
Beyond the Conceivable
}




\section{WEIMAR AND NOW: GERMAN CULTURAL CRITICISM}

Edward Dimendberg, Martin Jay, and Anton Kaes, General Editors

1. Heritage of Our Times, by Ernst Bloch

2. The Nietzsche Legacy in Germany, 1890-1990, by Steven E. Aschheim

3. The Weimar Republic Sourcebook, edited by Anton Kaes, Martin Jay, and Edward Dimendberg

4. Batteries of Life: On the History of Things and Their Perception in Modernity, by Christoph Asendorf

5. Profane Illumination: Walter Benjamin and the Paris of Surrealist Revolution, by Margaret Cohen

6. Hollywood in Berlin: American Cinema and Weimar Germany, by Thomas J. Saunders

7. Walter Benjamin: An Aesthetic of Redemption, by Richard Wolin

8. The New Typography, by Jan Tschichold, translated by Ruari McLean

9. The Rule of Law under Siege: Selected Essays of Franz L. Neumann and Otto Kirchheimer, edited by William E. Scheuerman

10. The Dialectical Imagination: A History of the Frankfurt School and the Institute of Social Research, 1923-1950, by Martin Jay

11. Women in the Metropolis: Gender and Modernity in Weimar Culture, edited by Katharina von Ankum

12. Letters of Heinrich and Thomas Mann, 190o-1949, edited by Hans Wysling, translated by Don Reneau

13. Empire of Ecstasy: Nudity and Movement in German Body Culture, 1910-1935, by Karl Toepfer

14. In the Shadow of Catastrophe: German Intellectuals between Apocalypse and Enlightenment, by Anson Rabinbach

15. Walter Benjamin's Other History: Of Stones, Animals, Human Beings, and Angels, by Beatrice Hanssen

16. Exiled in Paradise: German Refugee Artists and Intellectuals in America from the I930s to the Present, by Anthony Heilbut

17. Cool Conduct: The Culture of Distance in Weimar Germany, by Helmut Lethen, translated by Don Reneau

18. In A Cold Crater: Cultural and Intellectual Life in Berlin, 1945-1948, by Wolfgang Schivelbusch, translated by Kelly Barry

19. A Dubious Past: Ernst Jünger and the Politics of Literature after Nazism, by Elliot Y. Neaman

20. Beyond the Conceivable: Studies on Germany, Nazism, and the Holocaust, by Dan Diner 
21. Prague Territories: National Conflict and Cultural Innovation in Kafka's Fin de Siècle, by Scott Spector

22. Munich and Memory: Architecture, Monuments, and the Legacy of the Third Reich, by Gavriel D. Rosenfeld

23. The UFA Story: A History of Germany's Greatest Film Company, 1918-1945, by Klaus Kreimeier, translated by Robert and Rita Kimber

24. From Monuments to Traces: Artifacts of German Memory, 1870-199o, by Rudy Koshar

25. We Weren't Modern Enough: Women Artists and the Limits of German Modernism, by Marsha Maskimmon 
To my mother

Chana Diner, née Isakson 


\section{Beyond the Conceivable}

Studies on Germany, Nazism, and the Holocaust

\section{Dan Diner}


This book is a print-on-demand volume. It is manufactured using toner in place of ink. Type and images may be less sharp than the same material seen in traditionally printed University of California Press editions.

University of California Press

Berkeley and Los Angeles, California

University of California Press, Ltd.

London, England

우 2000 by Dan Diner

The chapters in this book are revised versions of the following studies: Chapter 1: "Constitutional Theory and 'State of Emergency' in the Weimar Republic: The Case of Carl Schmitt," Tel Aviver Jahrbuch für deutsche Geschichte 17 (1988): 303-21. Chapter 2: "'Grundbuch des Planeten': Zur Geopolitik Karl Haushofers," Vierteljahrshefte für Zeitgeschichte 32 (1984): 1-28. Chapter 3: "Rassistisches Völkerrecht: Elemente einer nationalisozialistischen Weltordnung," Vierteljahrshefte für Zeitgeschichte 37 (1989): 23-56. Chapter 4: "Die Katastrophe vor der Katastrophe: Auswanderung ohne Einwanderung," in 7erbrochene Geschichte: Leben und Selbstverständnis der Juden in Deutschland, ed. Dirk Blasius and Dan Diner (Frankfurt am Main: S. Fischer Verlag, 1991), 138-6o. Chapter 5: "Aporie der Vernunft: Horkheimers Überlegungen zu Antisemitismus und Massenvernichtung," in Zivilisationsbruch: Denken nach Auschwitz, ed. Dan Diner (Frankfurt am Main: S. Fischer Verlag, 1988), 30-53. Its English version is "Reason and the 'Other': Horkheimer's Reflections on Anti-Semitism and Mass Aunihilation, " in On Max Horkheimer-New Perspectives, ed. Seyla Benhabib, Wolfgang Bon $B$, and John McCole (Cambridge, Mass.: MIT Press, 1993), 335-63. Chapter 6: "Jenseits des Vorstellbaren - der 'Judenrat' als Situation," in Unser einziger Weg ist Arbeit: Das Ghetto in Lodz 1940-1944, ed. Hanno Loewy and Gerhard Schoenberner (Vienna: Lōcker Verlag, 1990), 32-40. Chapter 7: "Historical Understanding and Counterrationality: The Judenrat as Epistemological Vantage," in Probing the Limits of Representation, ed. Saul Friedländer (Cambridge, Mass.: Harvard University Press, 1992), 128 42. Chapter 8: "Rationalisierung und Methode: Zu einem neuen Erklärungsversuch der Endlösung," Vierteljahrshefte für Zeitgeschichte 4o (1992): 359-82. Its English version is "Rationalization and Method: Critique of a New Approach in Understanding the 'Final Solution,'" Yad Vashem Studies 24 (1994): 71-108. Chapter 9: "Historical Experience and Cognition: Perspectives on National Socialism," History E Memory: Studies in Representation of the Past 2 (1990): 84105. Chapter 10: "Varieties of Narration: The Holocaust in Historical Memory," in Studies in Contemporary Jewry: The Fate of the European Jews, 1939-1943, ed. Jonathan Frankel (New York: Oxford University Press, 1997), 84-100. Chapter 11: "Nationalsozialismus und StalinismusÜber Gedāchtnis, Willkür, Arbeit und Tod," Babylon: Beiträge zur jüdischen Gegenwart 10-11 (1992): 1 10-24. Chapter 12: "Cumulative Contingency: Historicizing Legitimacy in Israeli Discourse," History E् Memory: Studies in Representation of the Past 7 (1995): 147-67. Chapter 13: "On Guilt-Discourse and Other Narratives. Epistemological Observations regarding the Holocaust," in History $\mathcal{E}$ Memory, Passing into History: Nazism and the Holocaust beyond Memory, In Honor of Saul Friedländer on His Sixty-Fifth Birthday, ed. Gulie Ne'eman Arad (Bloomington: Indiana University Press, 1997), 301-21.

Library of Congress Cataloging-in-Publication Data appears at the back of this book.

Manufactured in the United States of America

The paper used in this publication meets the minirnum requirements of ANSI/NISO z39.48$199^{2}$ (R 1997) (Permanence of Paper). 